peutic agent in a limited trial in advanced breast cancer. A transient improvement was noted in six of 27 women. ${ }^{38}$ Mifepristone may also have a place in treating endometriosis ${ }^{1}$ and certain types of meningioma. ${ }^{39}$

\section{Social, legal, and ethical issues}

Despite its potential wide usefulness many antiabortion bodies have united to oppose RU 486. They make the point that a black market for the drug could develop, with associated medical hazards. But such problems are more, not less, likely if the drug is driven underground. As Baird pointed out: "The valid point for discussion is whether it is ethical to carry out therapeutic abortion under any circumstances. While it is legal to carry out therapeutic abortion, surely it is incumbent on medical scientists to develop safe and effective means which will preserve the health of women?"11

In October 1988- on the day after the French marketing licence was given - the manufacturer suspended all sales. Although the largest holder of Roussel-Uclaf stock is the French government, over $36 \%$ is held by Hoechst of West Germany. Hoechst had earlier been accused of (but denied) manufacturing the poison gas used in Nazi concentration camps. Its management may have been afraid that opponents to abortion would revive this calumny; it brought heavy pressure on Dr Sakiz, the president of Roussel-Uclaf, to suspend sales. (It is a bizarre paradox of twentieth century history that Adolf Hitler explicitly condemned abortion as immoral. ${ }^{4}$ ) Two days later the French government ordered the company to resume distribution of the drug. Health minister Claude Evin said that executives of the company had been subjected to "scandalous pressure," which included anonymous threats to their wives and children. The drug, ordered Evin, should be made available "in the interest of

1 Baulieu E-E. RU-486 as an antiprogesterone steroid: from receptor to contragestion and beyond. ЭAMA 1989;262:1804-14.

2 Milgrom E, Atger $M$, Baulieu E-E. Progesterone in uterus and plasma, IV: progesterone receptor in guinea pig uterus cytosol. Steroids 1970;16:741-54

3 Philibert D, Deraedt R, Rournemine C, et al. RU 38486-an antiglucocorticoid with a new mechanism of antihormone activity. I Steroid Biochem 1982;17:68.

4 Potts M. RU 486: termination of a pregnancy in the privacy of one's home. NC Med $\mathcal{F}$ 1989;50: $531-6$

5 Herrmann W. The clinical use of RU 486 (mifepristone). Research in Reproduction 1989;21:3.

6 Baird DT. The use of antigestagens in fertility regulation. British fournal of Family Planning 1988;13(suppl):11-3.

7 Csapo AL, Pulkkinen MO. Indispensability of the human corpus luteum in the maintenance of early pregnancy. Obstet Gynecol Surv 1978;33:69-81.

8 Deraedt R, Bonnat C, Busigny M, et al. Pharmacokinetics of RU 486. In: Baulieu E-E, Segal SJ eds. The antiprogestin steroid RU 486 and human fertility control. New York: Plenum Press 1985 . $103-22$.

9 Stuenkel CA, Garzo VG, Morris S, et al. Effects of the antiprogesterone RU 486 in the early follicular phase of the menstrual cycle. Fertil Steril 1990;53:642-6.

10 Luukkainen T, Heikinheimo O, Haukkamaa $M$, et al. Inhibition of folliculogenesis and ovulation by the antiprogesterone RU 486. Fertil Steril 1988;49:961-3.

1 Baird DT. An update on the use of antigestagens in fertility control. British fournal of Family Planning 1990;15(suppl):44-7.

$12 \mathrm{Liu} \mathrm{JH}$, Yen SS. Induction of midcycle gonadotropin surge by ovarian steroids in women: a critical evaluation. F Clin Endocrinol Metab 1983;57:797-802.

13 Kekkonen R, Alfthan H, Haukkamaa $M$, et al. Interference with ovulation by sequential treatment with the antiprogesterone RU 486 and synthetic progestin. Fertil Steril 1990;53:747-50.

14 Garzo VG, Liu J, Ulmann A, Baulieu E-E, Yen SS. Effects of an antiprogesterone (RU 486) on the hypothalamic-hypophyseal-ovarian-endometrial axis during the luteal phase of the menstrual cycle. $\mathcal{F}$ Clin Endocrinol Metab 1988;66:508-17.

15 Schaison G, George M, Lestrat N, Reinberg A, Baulieu E-E. Effects of the antiprogesterone steroid RU 486 during mid-luteal phase in normal women. I Clin Endocrinol Metab 1985;61:484-9.

6 Van Santen MR, Haspels AA. Interception III: postcoital luteal contraception by an antiprogestin mifepristone (RU 486) in 62 women. Contraception 1987;35:423-31.

17 Dubois C, Ulmann A, Baulieu E-E. Contragestion with late luteal administration of RU 486 (mifepristone). Fertil Steril 1988;50:593-6.

18 Lahteenmaki P, Alfthan H, Rapeli T, et al. Late postcoital treatment against pregnancy with antiprogesterone RU 486. Fertil Steril 1988;50:36-8.

19 Yuzpe AA, Lancee WJ. Ethinylestradiol and dl-norgestrel as a postcoital contraceptive. Fertil Steri 1977;28:932-6.

20 Rowlands S, Guillebaud J, Bounds W, Booth M. Side effects of anazol compared with an ethinyloestradiol/norgestrel combination when used for postcoital contraception. Contraception 1983;27:39-49.

21 Bygdeman M, Swahn M-L. Progesterone receptor blockage. Effect on uterine contractility and early pregnancy. Contraception 1985;32:45-51.

22 Cameron IT, Michie AF, Baird DT. Therapeutic abortion in early pregnancy with antiprogesterone RU 486 alone or in combination with prostaglandin analogue (gemeprost). Contraception 1986;34:459-67.

23 Rodger MW, Baird DT. Blood loss following induction of early abortion using mifepristone (RU 486) and a prostaglandin analogue (gemeprost). Contraception 1989;40:439-47.

24 Rodger MW, Baird DT. Induction of therapeutic abortion in early pregnancy with mifepristone in combination with prostaglandin pessary. Lancet 1987;ii: 1415-8. public health." Voluntary abortion was legalised in France in 1975 and was now "a right for women ... withdrawing the pill would deprive women of an important scientific advance that makes abortions less painful and traumatic by avoiding the need for surgery." 40

Probably more than one third of the 140 million women in the developing world who became pregnant in 1988 did not want to have another child. ${ }^{41}$ Extrapolating from available data, one third to two thirds of the 25 to 40 million abortions in developing countries are illegal procedures or take place outside the health system and have a high mortality and morbidity. ${ }^{41}$ Clearly there is a great unmet need for contraception, but also, in the real world, there is a need for the mifepristone and prostaglandin combination with all necessary legal safeguards - plus counselling and medical back up for failure of the method or heavy bleeding.

Britain is expected to be the next country after France in which mifepristone is marketed. Indeed, the company last month announced that it would seek a marketing licence in the United Kingdom. ${ }^{42}$ Allowing for the inevitable delay in obtaining full approval from the Committee on the Safety of Medicines, marketing is unlikely before the end of 1991. In Britain "the introduction of RU 486 could result in a saving to the NHS of $£ 10-15 \mathrm{~m}$ annually .. . with an anticipated reduction in patient morbidity an added advantage." ${ }^{43}$

The International Planned Parenthood Federation, in a statement at the meeting in Ottawa in November 1989, expressed its deep concern over the lack of progress in making these products available to women. It deplored the delays ${ }^{44}$; so, I am sure, will most readers of the $B M \mathcal{H}$.

JOHN GUILLEBAUD

Medical Director,

Margaret Pyke Centre,

London WIV 5TW

25 Rodger MW, Logan AF, Baird DT. Induction of early abortion with mifepristone (RU 486) and two different doses of prostaglandin pessary (gemeprost). Contraception 1989;39:497-502.

26 Swahn M-L, Gottlieb C, Green K, Bygdeman M. Oral administration of RU 486 and 9-methyline $\mathrm{PGE}_{2}$ for termination of early pregnancy. Contraception 1990;41:461-73.

27 Cameron IT, Baird DT. A controlled released form of 16-16-dimethyl-trans $\Delta_{2} 2 \mathrm{PGE}_{1}$ methyl ester for early abortion. Contraception 1986;33:121-5.

28 Laboratoires Roussel. Mifégyne (mifepristone): brochure d'information scientifique. Paris: Laboratoires Roussel, 1989:1-36.

29 Radestad A, Christensen NJ, Stromberg L. Induced cervical ripening with mifepristone in first trimester abortion: a double blind randomised biochemical study. Contraception 1988;38:301-12.

30 Gupta JK, Johnson N. Effect of mifepristone on dilatation of the pregnant and non-pregnant cervix. Lancet 1990;335:1238-40.

31 Christensen NJ, Bygdeman M, Green K. Comparison of different prostaglandin analogues and laminaria for pre-operative dilatation of the cervix in late first trimester abortion. Contraception 1983;27:51-61.

32 Rodger MW, Baird DT. Pre-treatment with mifepristone RU 486 reduces interval between prostaglandin administration and expulsion in second trimester abortion. Br $\mathcal{Y}$ Obstet Gynaecol 1990;97:41-5.

33 Cabrol D, D'Yvoire MB, Mermet E, Cedard L, Sureau C, Baulieu E-E. Induction of labour with mifepristone after intrauterine fetal death. Lancet 1985 ;ii: 1019

34 Wolf JF, Sinosich M, Anderson TL, Ulmann A, Baulieu E-E, Hodgen GD. Progesterone antagonist (RU 486) for cervical dilatation, labor induction and delivery in monkeys. Effectiveness in combination with oxytocin. Am f Obstet Gynecol 1989;160:45-7.

35 Hill NC, Selinger M, Ferguson F, MacKenzie IZ. The placental transfer of mifepristone (RU 486) during the second trimester and its influence upon maternal and fetal steroid concentrations. Brf Obstet Gynaecol 1990;97:406-11.

36 Paris FX, Henry-Suchet J, Tesquier L, Logsel T, Loffredo V, Pez JP. Le traitment medical des grossesses extra-uterines par le RU 486. Presse Med 1984:13:1219.

37 Bertagna X, Bertagna C, Laudat M-H, Husson JM, Girard F, Luton P. Pituitary-adrenal responses to the antiglucocorticoid action RU 486 in Cushing's syndrome. $f$ Clin Endocrinol Metab to the antigluce
$1986 ; 63: 639-43$.

38 Romieu G, Maudelonde T, Ulmann A, et al. The antiprogestin RU 486 in advanced breast cancer: preliminary clinical trial. Bull Cancer 1987;74:455-61.

39 Blankenstein MA, van't Verlat JW Croughs RJ. Hormone dependency of meningiomas. Lancet $1989 ; 1: 1381$.

40 Dorozynski A. Tempest in a pill box. Br Med f 1988;297:1291-2.

41 Anonymous. The impact of unsafe abortion in the developing world. Outlook 1989;7:2-7.

42 Prentice T. French hope to market abortion pill in Britain. The Times 1990;23 Jul:4.

43 MacKenzie IZ. RU 486 and the implications for the NHS. In: The abortion pill RU 486. London: Birth Control Trust, 1990.

44 Anonymous. Resolution on RU 486. IPPF Medical Bulletin 1989;23:3-4.

\section{Correction}

Who should take vitamin supplements?

An editorial error occurred in the editorial by Professor Stewart Truswell ( 21 July, p 135). Thiamine ranges from 0.5 to $50 \mathrm{mg}$ per tablet and not $5.0 \mathrm{mg}$ as published. 